\title{
Speaking the Same Language: Data Standards and Disruptive Technologies in the Administration of Justice
}

\author{
David Colarusso* \& Erika J. Rickard**
}

\section{INTRODUCTION}

While the legal profession is coming to grips with technological disruption, practitioners serving the needs of those with low and moderate-incomes find themselves struggling to keep up. ${ }^{1}$ Insufficient resources clearly impede largescale technological improvements. Yet, the rise of civic coding and the growing legal technology sector suggest an untapped pool of civic and private resources ready to help address this shortfall. ${ }^{2}$ We argue that state trial courts are best positioned to leverage these resources for the benefit of low and moderateincome individuals by addressing a key structural impediment to innovation: the lack of clearly-defined judicial data standards.

In private practice and legal education, innovative technologies have fueled competition from companies that provide document automation to the general public and leverage machine intelligence to remove the work of repetitive tasks, including matters involving rudimentary questions of judgment. ${ }^{3}$ While

* Data Scientist, Massachusetts Committee for Public Counsel Services (CPCS); J.D., Boston University School of Law (2011); M.Ed., Harvard Graduate School of Education (2002). The opinions expressed here are the author's own and do not reflect those of CPCS or the Commonwealth of Massachusetts.

** Associate Director of Field Research, Access to Justice Lab at Harvard Law School, and Commissioner, Massachusetts Access to Justice Commission; J.D., Harvard Law School (2010). Portions of this Article derive from presentations made by the authors at the 2016 Suffolk University Law Review's Legal Technology Symposium entitled, "A New Era of Lawyering: Integrating Law Practice with Innovative Technology." Additional portions were adapted from a CPCS blog post accompanying a public comment in reply to the Massachusetts Trial Court's 2016 proposed rule change regarding access to court records. Many thanks to CPCS Chief Information Officer, Daniel Saroff, who assisted greatly in the drafting of the comment and blog post. Many thanks as well to Professor Gabe Teninbaum, Judge Dina Fein, Harvard Law School Library Innovation Lab Director, Adam Ziegler, the editors of the Suffolk University Law Review, and the community of writers at Lawyerist for their title suggestions, particularly Andrew Cabasso.

1. See Clayton M. Christensen, The Innovator's Dilemma: When New Technologies Cause GREAT FIRMS TO FAIL xii-xiii (1997) (analyzing effects of disruptive technology on well-managed companies); see also Raymond H. Brescia et al., Embracing Disruption: How Technological Change in the Delivery of Legal Services Can Improve Access to Justice, 78 ALB. L. REV. 553, 555-66 (2015) (discussing The Innovator's Dilemma and technological disruption in the legal profession).

2. See Overview, TECHINDEX, http://techindex.law.stanford.edu (last visited Apr. 6, 2017) [https://perma.cc/7AYT-RJ3P] (representing such advances and outlining services offered); Who We Are, CODE FOR AMERICA, https://www.codeforamerica.org/who (last visited Apr. 6, 2017) [https://perma.cc/QCN4-ATJC] (describing the civic coding work provided by the nonprofit organization, Code for America).

3. See Gerard J. Clark, Internet Wars: The Bar Against the Websites, 13 J. HigH TECH. L. 247, 270 
lawyers can debate the relative merits and drawbacks of this emerging paradigm shift, the adoption of modern information technology is undeniably a game-changer for all parties involved. Meanwhile, such technology has begun to deliver only a fraction of the disruption long predicted by scholars and practitioners in the access to justice world.

We argue that the primary obstacles to utilizing technology to increase access to justice lie in the state trial courts. Court systems, like legal aid programs and the private bar, have begun to adopt new technologies, both internally and externally. However, tech tools are often added to existing structures and schema of court administration with little consideration for how the parts fit into the whole, or how such changes provide opportunities for reforming existing practices. This Article calls for a reimagining of current practice. While we are not the first to suggest a redesign, we propose a catalyst — open data standards.

We see data standards as both a critical part of well-functioning court systems and a fulcrum for leveraging technology to drive system change. Section II provides an overview of open data standards, including a historical look at their use in the law, and examples of successful twenty-first century implementations by executive branch agencies. Section III provides context for the access to justice movement, and its current efforts to harness technology for the benefit of those with legal needs. Section IV focuses on how establishing data standards for electronically sharing information across the justice system would propel existing technological innovations to greater prominence and effectiveness. Section V takes the idea one step further, posing data standards as the missing ingredient to broader thinking about improving access to justice in the twenty-first century through state courts. ${ }^{4}$

\section{THE CATALYST: DATA STANDARDS}

If an argument over the use of one or two spaces post-punctuation has ever concluded with blows, a lawyer likely threw the first punch. ${ }^{5}$ Form matters.

(2013) (noting, for example, LegalZoom's "automated online checks" and reviews of documents). Machine intelligence is disrupting the legal profession in the areas of discovery, document automation, predictive analysis, and even the generation of legal briefs and pleadings. John O. McGinnis \& Russell G. Pearce, The Great Disruption: How Machine Intelligence Will Transform the Role of Lawyers in the Delivery of Legal Services, 82 FORDHAM L. REV. 3041, 3046 (2014) (indicating improved predictive analytics affect all areas of legal technological change); see also Clark, supra, at 295-96 (positing law firms will outsource and produce ediscovery at "more sophisticated level" firms).

4. See Deborah L. Rhode, Access to Justice 100 (2004) (considering courts policymakers, administrators, and judicial decision-makers).

5. Compare Farhad Manjoo, Space Invaders: Why You Should Never, Ever Use Two Spaces After a Period, SLATE (Jan. 12, 2011), http://www.slate.com/articles/technology/technology/2011/01/space_ invaders.html (arguing for one space based on typography industry-consensus), with Heraclitus, Why Two Spaces After a Period Isn't Wrong (or, The Lies Typographers Tell About History), HERACLITEAN RIVER (Nov. 1, 2011), http://www.heracliteanriver.com [https://perma.cc/6L9C-C3U6] (considering one space argument 
The legal community codifies proper form in court rules and adopts standards of citation in service of clarity and efficiency. The effort of deciphering an author's meaning is a tax on their argument, one that the legal community has done its best to abolish. Form matters in part because it should not matter. ${ }^{6}$ Standards allow those engaging with a document to access its content more easily. This understanding is the core of legal practice. ${ }^{7}$ So it is surprising that the legal community has largely failed to carry this insight into the digital age. When the final product is a printed document with one-inch margins, and the intended reader is a person, no self-respecting court would consider forcing parties to adopt a monolithic technical solution, for example, requiring that all filings be typed on a 1939 Underwood Universal typewriter. However, in the digital realm, many courts are happy to do just that. ${ }^{8}$ This is likely due to a conflation of software products with the tasks they perform. The printed document represents a well-defined standard, and parties are free to produce compliant documents however they prefer.

In the early days of English common law, those writing the Year Books (reports of pleas before the common bench) found it sufficient when citing cases to use monikers such as "casum la dame de Gild" meaning "the case of the lady of Gild." 9 Such conventions, and the memories of individual lawyers, however, proved inadequate at indexing the entirety of English case law. ${ }^{10}$

based on false historical accounts). Tongue firmly in cheek, as a matter of probabilities, the number of people with the job title lawyer outnumbers that of other clearly delineated writing professions. See A-Z Index, Occupational Outlook Handbook, BUREAU LAB. STATS., https:/www.bls.gov/ooh/a-z-index.htm (last visited Apr. 6, 2017) [https://perma.cc/D42S-E7UH] (showing the number of lawyers, 778,700, to far exceed that of writers and authors, 136,500).

6. See generally Marshall Mcluhan \& Quentin Fiore, The Medium Is the Massage: AN INVENTORY OF EFFECTS (1967) (providing overview and analysis of messaging). It has been argued that the medium is the message, and there is ample social science to support the argument that context, including form, can influence cognition. See id. at 8-10. For example, consider the havoc that ensues when asked to read the name of a color printed in a hue other than the color the word describes. See John Ridley Stroop, Studies of Interference in Serial Verbal Reactions, 18 J. EXPERIMENTAL PsychOL. 643, 644-45 (1935) (detailing psychological experiment underpinning Stroop effect). The authors of this Article intend to engage with the question of form in an idealized sense. It may be that a piece's form can influence a reader's impression of content, especially when conventions of form are ignored. And it is also true that the art of persuasion can lean heavily on the exploitation of cognitive biases, such that the true substance of an argument is often intentionally obscured, but it is clearly the goal of standardized formatting to minimize these extraneous influences.

7. Cf. Richard A. Posner, What Is Obviously Wrong with the Federal Judiciary, Yet Eminently Curable, 19 GREEN BAG 2D 187, 197 (2016), http://www.greenbag.org/v19n2/v19n2_articles_posner.pdf [https://perma. cc/DLA5-3FZH] (stating "[c]larity, not eloquence, is the only attainable . . . literary goal of modern judicial writing").

8. See infra note 69 and accompanying text (explaining courts requiring electronic filing).

9. See Maxstoke v. Martyn, Y.B. 2 Rich. 2, Trin., pl. 6 (1378), reprinted in 1 YEAR BOOKS OF RICHARD II: 2 RichARD II, 1378-1379 22 (Samuel E. Thorne et al. eds., Ames Foundation Year Book Series, 1975) (citing case establishing widows' property rights). This instance was brought to our attention thanks to the work of Byron D. Cooper. See Byron D. Cooper, Anglo-American Legal Citation: Historical Development and Library Implications, 75 L. LIBR. J. 3, 6 (1982) (discussing English Year Books).

10. See Cooper, supra note 9, at 6-7 (discussing English origins of history of legal citation). 
Today we avoid reliance on memory through the application of standard citation and reference to common court reporters. ${ }^{11}$ Now imagine a different world, one in which each courthouse maintains its own library containing the entirety of all case law, painstakingly transcribed by the court clerk into idiosyncratically paginated, sequentially numbered, three-ring binders.

To cite a case under this system, one is required to reference the binder and page number of the case as recorded in that court's library. Instead of abolishing our decipherment tax, the courts have shifted costs to those operating between courts, and they have made cost sharing among the courts impossible. This new cost works to erect walls around individual courts, shutting them off from larger communities. This is the world legal technologists see today, one in which the failure to adopt clear standards concerning the formatting of data impedes the development of digital solutions at scale, while imposing real costs on those wishing to access justice.

\section{A. Data Standards Explained}

In the context of modern information technology, data standards are the rules under which one stores data, including the data's format. For example, if the court transmits a date to the jail requesting the transport of an inmate, it would be efficient if that date were added automatically to the prison's calendaring system. ${ }^{12}$ Before this can happen, however, the prison's system must know how the court writes dates. Consider that it is customary for Americans to write dates in the format of month, day, and year, while much of the world makes use of the format day, month, and year. ${ }^{13}$ Dates written in these formats risk ambiguity if a day falls within the first twelve days of the month, or if the reader is inattentive. ${ }^{14}$ Cultural conventions normally operate to avoid such ambiguity. Yet when sharing information across cultures, a failure to explicitly discuss such norms can end badly, such as in the loss of a $\$ 125$ million-dollar space mission. ${ }^{15}$

Data standards serve as a digital lingua franca, providing all parties involved

11. See id. at 17-23 (discussing historical and current American legal citation systems).

12. See Specifications, ICALENDAR, https://icalendar.org/RFC-Specifications/all (last visited Apr. 6, 2017) [https://perma.cc/U9FW-4LQ2] (describing history and specifications of common standard for communication of calendar events).

13. The ordering of four-digit year, two-digit month, and two-digit day, used widely by computer programmers, benefits from the fact that a simple sorting from smallest to largest produces a chronological ordering.

14. See David Bixenspan, UK Media Locked Out of White House Amidst Confusion Over Date Formatting, MEDIAITE (Jan. 27, 2017), http://www.mediaite.com/online/uk-media-locked-out-of-white-houseamidst-confusion-over-date-formatting [https://perma.cc/9XCU-Py4Y] (discussing some foreign reporters' inability to attend White House press conferences because of date formatting issue).

15. See Lisa Grossman, Nov. 10, 1999: Metric Math Mistake Muffed Mars Meteorology Mission, WIRED (Nov. 10, 2010), https://www.wired.com/2010/11/1110mars-climate-observer-report [https://perma.cc/EB59$5 \mathrm{PMG}$ ] (explaining software using different measurements failed to correctly interact, leading to disaster). 
the reassurance that they start on the same page. Attorneys often become aware of such standards when encountering their absence. Many attorneys have noticed this absence when attempting to open a WordPerfect file in Microsoft Word or vice versa. Attorneys come away from this experience concerned that unless you use tools from the same vendors, something will always be lost in translation. This is a flawed conclusion, however, and a dangerous one to make in the realm of court-approved software. It is true that unless each tool makes use of the same standards, translations will suffer, but there is nothing precluding different tools from making use of the same standards. In the case of WordPerfect and Microsoft Word, the use of proprietary internal standards leads to a breakdown in translation. Such closed standards have long been part of a developer's business model. Yet, standards need not be closed.

Open standards, those that are publicly shared, explained, and available for anyone to use, can serve as the foundation for successful, generally accessible software solutions. In fact, the World Wide Web is proof of the power of open standards. Hyper Text Markup Language (HTML), the language that specifies the content of a web page, is an open standard. ${ }^{16}$ Governed by the World Wide Web Consortium, it is nothing more than a set of specifications curated and published by an international standards organization. The World Wide Web is built on technology that implements these standards, and so the publisher of a website can be confident in the fact that visitors from all over the world will start on the same page. Standards help facilitate innovation by removing the decipherment tax discussed above.

Courts too often fail to recognize open standards as an alternative to the decipherment tax. They mistakenly believe that quality control requires the same brand of tools. Consequently, they enter exclusive contracts with vendors and grant them a monopoly over all aspects of service. This is analogous to the monopoly of court reporters, which, although at one time useful in the development of standard citations, is starting to show its age. ${ }^{17}$ More importantly, courts feel there is little they can do to foster technological innovation short of developing or purchasing large-scale technology solutions. Courts mistakenly believe they must do it all-they must build or buy a particularized solution for each of their many stakeholders.

These stakeholders, including the public, law enforcement, attorneys, and other governmental agencies, have unique needs regarding their interactions with court data. Consider the options available to a court wishing to make these interactions possible over the web. Providing each stakeholder with his

16. See WWW, https://www.w3.org/html (last visited Apr. 6, 2017) [https://perma.cc/D7P4-64MP] (considering HTML "the standard markup language[,] . . . and its elements form the building blocks of all websites").

17. See 2017-The Year to Free California's Case Law "For Publication By Any Person," Citing Blog (Jan. 9, 2017), http://citeblog.access-to-law.com [https://perma.cc/6Y2C-37WG] (illustrating move from print to electronic materials based on issues with print reporters). 
or her own idiosyncratic web portal, including their own secure electronic access or user interface, is costly and time-consuming. Fortunately, the courts need not bear this burden.

Given a standard for court data, a state court system could implement a single access point for all parties seeking access to their data. ${ }^{18}$ This access point would operate as a place for computer programs to securely exchange standardized data, including everything from requests for court information to electronic filings. This exchange is often implemented through an interface designed specifically for other computer programs, known as an application programming interface (API). APIs are often just websites that accept and output structured data. In both cases, the data returned would be structured data, conforming to a set of well-defined data standards. ${ }^{19}$ This structure could be as simple as tables with a set of predefined column names, or it could be more complex, like a nested set of Extensible Markup Language (XML) entities along with an attached data file. ${ }^{20}$ Likewise, users could upload data in a similarly structured form.

A person, however, would never visit these URLs in their web browser. Rather, a program would visit them on the user's behalf and incorporate their output into a value-added service, for example, pushing alerts to a user about upcoming court dates. In this way, the courts could provide a foundation upon which both the courts and other parties may build. The courts need not provide stakeholders with typewriters to receive typed pleadings. A court is free to do so, but it is not a requirement. Additionally, the more widely adopted a standard, the more easily products developed for one class of users can be adapted for others. Standards make solutions scalable.

A court API is only one example of how data standards can produce efficiencies. A court dead set against web-based access to data could benefit from adopting standards as well. Making sure that all internal systems are standards-compliant improves internal information sharing. When courts purchase multiple solutions from a single vendor, they achieve seamless internal information sharing because vendor systems all operate under a common standard. Requiring systems that are compliant with open standards avoids vendor lock-in where one has to keep using the same vendor because no other product can read the data. ${ }^{21}$

18. See Comm. for Pub. Counsel Servs., Supporting an Open Standards Approach for MassCourt Data, Pub. Def. Agency MassachuSETTS (Apr. 22 2016), https://www.publiccounsel.net/blog/2016/04/22/datastandards-api [https://perma.cc/HP5J-YV7D] (promoting open data standards approach for Massachusetts trial courts).

19. See OAuTH, https://oauth.net (last visited Apr. 6, 2017) [https://perma.cc/RC7Y-UF8W] (introducing authorization framework for third parties to obtain access to applications).

20. See Extensible Markup Language (XML), WwW, https://www.w3.org/XML (last visited Apr. 6, 2017) [https://perma.cc/ 5SU3-LRRH] (considering XML “a simple, very flexible text format").

21. See No-Cost Improvements to Child Support Enforcement: Hearing on H.R. 10 Before the Subcomm. on Human Resources of the H. Comm. on Ways and Means, $112^{\text {th }}$ Cong. 27 (2012) (statement of Craig D. 


\section{B. Privacy and Security Concerns}

Successful examples of open data standards are often cited in relation to the open data movement. ${ }^{22}$ Notably, open standards and open data are distinct from one another in that open standards, which are often paired with open data, are system protocols that allow users to share data freely and independently between competing vendors. ${ }^{23}$ Open data, on the other hand, refers to data that can be accessed and shared by the general public freely and with ease. ${ }^{24}$ For example, Emojis, the whimsical iconic images used by many to communicate via text, are standardized as part of a text standard administered by the Unicode Consortium. ${ }^{25}$ The fact that there is an open standard enumerating a common set of Emojis - that a wide number of technology companies have seen fit to support-has no bearing on whether or not an individual's text conversations are open to the world for anyone to read. The Unicode character set, including Emojis, is an open standard, which can be used to encode data that is itself not open. ${ }^{26}$ Of course, HTML falls into this category too. The fact that a bank's website is built on open standards in no way affects its ability to secure its clients' data. Likewise, the adoption of data standards need not limit a court's control over its data.

In fact, a number of law enforcement agencies already make use of a national data standard, the National Information Exchange Model (NIEM), to share sensitive information and facilitate e-filing of criminal complaints in some jurisdictions. ${ }^{27}$ The state public defender agency in Massachusetts, the

Burlingame, Chief Information Officer, Administrative Office of the Trial Court), https://waysandmeans.house.gov/UploadedFiles/Craig_Burlingame_Testimony_No_Watermark.pdf [https:// perma.cc/XEJ5-WUSX] (highlighting benefits attainable through implementation of technology standard). In his statement to the Subcommittee on Human Resources, Craig Burlingame stated, "[s]ound standards establish a technological vocabulary that allows parties with various perspectives to speak the same language when discussing electronic information and data exchanges. Further, the existence of quality standards provides a level playing field for the vendors that provide software and services to the governmental entities using them." Id.

22. See Bibiana McHugh, Pioneering Open Data Standards: The GTFS Story, in BeYOND TRANSParency: Open Data AND the Future OF Civic InNOvation 125, 125-26 (Brett Goldstein \& Lauren Dyson eds., 2013) (namely the inclusion of an open data standards article in book on open data).

23. See Open Standards, FSFE, https://fsfe.org/activities/os/def.en.html (last visited Apr. 6, 2017) [https://perma.cc/MC6C-BJBF] (providing widely adopted definition of open standards).

24. See Open Data, OPEN DATA HANDBOOK, http://opendatahandbook.org/glossary/en/terms/open-data (last visited Apr. 6, 2017) [https://perma.cc/BTR3-SDUH] (providing summary of concept of open data).

25. See Unicode Emoji, UNICODE, http://unicode.org/reports/tr51/index.html (last visited Apr. 6, 2017) [https://perma.cc/H8ME-FTRA] (providing Emoji's technical information to ensure conformance with Unicode standard).

26. See Hannah Miller et al., "Blissfully Happy" or "Ready to Fight": Varying Interpretations of Emoji, ICWSM-16 259 (2016), https://grouplens.org/site-content/uploads/ICWSM16_Emoji-Final_Version.pdf [https: //perma.cc/VP3Y-8GK5] (describing potential ambiguity of Emoji due to varying individual platforms); Jeremy Burge, Apple and The Gun Emoji, EMOJIPEDIA (Aug. 4, 2016), http://blog.emojipedia.org/apple-andthe-gun-emoji [https://perma.cc/L5L2-BNZP] (describing Apple's change of pistol Emoji to green water gun Emoji).

27. See John S. Hollywood \& Zev Winkelman, Nat'l Institute of Justice, Improving 
Committee for Public Counsel Services, recently argued in a public comment on new proposed court record rules, "[a]s the administrator of this access point, the Trial Court would maintain complete control over access based on whatever permissions it deemed appropriate, and could supply different data to different parties depending on need and confidentiality requirements." 28

\section{Where Open Data Standards Have Worked Before}

Federal, state, and municipal agencies have successfully deployed APIs built on open data standards, resulting in a proliferation of user-centered applications and web tools for everything from public transit to the delivery of city government services. ${ }^{29}$ If you were planning a trip in 2005, a number of online navigation services offered driving directions, but aside from local government trip planners, you would have been hard-pressed to find travel suggestions including public transit. ${ }^{30}$ If you were Bibiana McHugh, working as an IT manager for Portland, Oregon's public transit organization TriMet, you saw this as a problem that needed solving. ${ }^{31}$ McHugh reached out to the providers of several navigation products, asking if they would consider including Portland's data. ${ }^{32}$ This led to a meeting with some Google engineers, and within five months, Portland's data became the cornerstone of Google Transit. ${ }^{33}$ The TriMet team worked with Google to provide their data in a simple comma-separated value file, and their formatting was later codified into an open standard, what would come to be known as the General Transit Feed Specification (GTFS). ${ }^{34}$ The simplicity of this format allowed other agencies to easily publish their data in the new standard, and, as of this writing, Google Transit has launched in hundreds of cities around the world thanks to the use of GTFS data.

The GTFS standard made scaling possible because what works for one transit system works for any system using GTFS data. Remarkably, McHugh explains that "TriMet has not incurred any direct cost for this specific project,

\footnotetext{
INFORMATION-SHARING ACROSS LAW ENFORCEMENT: WHY CAN'T WE KNOW? 1-2 (2015), https://www. ncjrs.gov/pdffiles1/nij/grants/249187.pdf [https://perma.cc/B6N4-DV5D] (illustrating instances of law enforcement's use of NEIM system).

28. Comm. for Pub. Counsel Serv., supra note 18.

29. See John Carlo Bertot et al., Big Data, Open Government and E-Government: Issues, Policies and Recommendations, 19 INFO. PoliTy 5, 5-6 (2014) (describing changes to data governance, open data policies under Obama Administration). See generally DATA.gOv, https:/www.data.gov (last visited Apr. 6, 2017) [https://perma.cc/8QV3-MJV6] (highlighting open data tools); Highlights from the Open311 Ecosystem, OPEN311, http://www.open311.org (last visited Apr. 6, 2017) [https://perma.cc/86XG-APC7] (discussing purpose of website).

30. McHugh, supra note 22, at 125 (noting transit data available, but rarely put out for public online access).

31. Id. (noting "I knew such data was available and the potential was there").

32. Id. at $125-26$.

33. Id. at 126-27.

34. McHugh, supra note 22, at 126.
} 
except resource time, which is a very small investment in comparison to the returns." $" 35$ The TriMet example underscores the role data standards can play in scalability, along with the "light lift" asked of those adopting the standards; but the example does not end with transit data on Google Maps.

In the mid-2000s, the Massachusetts Department of Transportation (MassDOT) recognized that riders would benefit from the installation of digital signs to share transit alerts and bus/train arrival times. The installation of these displays would require major capital investment, and MassDOT projected the roll out would take years. In 2009, MassDOT was already collecting location data on a significant fraction of its fleet. They began publishing the data in a slightly tweaked version of GTFS, what would become GTFS real time (GTFSRT). ${ }^{36}$ MassDOT invited developers to build tools based on this data under the MassDOT Developer's Initiative. ${ }^{37}$ This standards-based approach offered developers the promise of portability and scalability, sparking the creation of dozens of transit apps and websites that serve MassDOT's riders-products that were developed at almost no cost to MassDOT, as the investment in tracking was part of a pre-existing plan to provide digital arrival signs. Again, many localities followed suit and adopted the standard; the solutions that worked in one locale were easily transferable to others. If you ever find yourself using your phone to check the location of the next bus, thank open standards.

The lessons here are not that open standards are a panacea, or that their adoption will allow courts to offload large technical builds to third parties. ${ }^{38}$ Rather, the act of adopting data standards and sharing those standards, not necessarily the data they encode, aids in developing scalable technical solutions, and perhaps most importantly, it is a concrete step that courts can easily take.

\section{The Courts Have Room to Grow}

Compared to executive branch agencies, the idea of open data standards is relatively new to state courts. ${ }^{39}$ The NIEM is one exception: a data standard used to share information between the judiciary and federal and state agencies

35. Id. at 130 .

36. See id. at 133 (referencing MBTA, a subsidiary of MassDOT). GTFS-RT was also developed in collaboration with TriMet, BART, and MTS. Id.

37. See Developers' Data Sources, MASs. Dep't TRANSPORTATION, https://www.massdot.state.ma.us/ DevelopersData.aspx (last visited Apr. 6, 2017) [https://perma.cc/7TR8-25UE] (highlighting program specifics).

38. To be clear, this is not a suggestion that courts offload work to civic hackathons, which are often limited in their scope and available resources.

39. Compare DATA.GOV, supra note 29 (providing public access to government data), with CCJ Resolution on Technology Standards, NAT'L CTR. FOR ST. CTS., http://www.ncsc.org/Services-andExperts/Technology-tools/Court-specific-standards/CCJ-Resolution.aspx (last visited Apr. 6, 2017) [https://perma.cc/65W9-ENJD] (resolving to begin implementation of data standards). 
to promote interoperability across multiple data sets. ${ }^{40}$ Developers launched NEIM in 2005 as a collaboration between the Department of Justice and the Department of Homeland Security. ${ }^{41}$ A number of courts have adopted NIEM or similar frameworks. ${ }^{42}$ The NIEM, like other national models, is essentially a meta-standard: a template for how states can use standard language to define the types of information that they share across organizations. ${ }^{43}$ Adopting a model like NIEM is therefore an essential first step towards comprehensive data standards. ${ }^{44}$

Some jurisdictions have begun to create common databases or data exchanges with individual state agencies on an ad hoc basis, often in reaction to specific requests, legislative mandates, or other needs. ${ }^{45}$ To date, fewer than a half-dozen courts across the United States have adopted a comprehensive data standard system despite efforts by entities such as the National Center for State Courts (NCSC) to help facilitate such adoption. ${ }^{46}$ Consequently, there is an

40. See NIEM's History, NIEM, https://www.niem.gov/about-niem/history (last visited Apr. 6, 2017) [https://perma.cc/Z4V2-H5JZ] (outlining formation of NIEM).

41. Id.; see also Thomas C. Carlson, The National Information Exchange Model: An Update, in NAT'L Ctr. for State Courts, Future Trends in State Courts 26, 26 (2007), http://www.ndcrc.org /sites/default/files/future_trends_2007.pdf [https://perma.cc/K4XW-JZFS] (describing Global Justice Data $\mathrm{XML}$ as "seed material" for NIEM).

42. NIEM is but one in a constellation of complementary (and competing) national data standards. See National Standards, NAT'L CTR. FOR ST. CTS., http://www.ncsc.org/Services-and-Experts/Technologytools/National-standards.aspx (last visited Apr. 6, 2017) [https://perma.cc/YCA2-SV5D] (listing various competing standards). Other national standards initiatives in the state justice system space include Legal XML, a nonprofit that sets data standards specific to legal systems, including electronic court filing. About LegalXML, LEGALXML, http://www.legalxml.org/about/index.shtml (last visited Apr. 6, 2017) [https://perma.cc/6JLM-3ZQ9] (introducing legal consortium sector). Data standards like LegalXML can also adopt NIEM's data architecture - a state court that utilizes the LegalXML standard for electronic court filing will also conform with NIEM standards. See Electronic Court Filing Version 4.01 Plus Errata 01, OASIS 9-11 (July 14, 2014), http://docs.oasis-open.org/legalxml-courtfiling/specs/ecf/v4.01/ecf-v4.01-spec/ecf-v4.01spec.pdf [https://perma.cc/7GHD-JTDL] (explaining LegalXML worked with NIEM when developing ECF 4.0 , its model for electronic court filing).

43. A broad framework that can be applied to everything from emergency management to immigration to justice information exchanges, the NIEM is not intended to cover every data specification that state-level justice systems may require, particularly regarding civil cases.

44. See HollywoOd \& WinKelman, supra note 27, at 21 (stating "existing standards . . . are partial and inconsistent, and NIEM ... [is] necessary but not sufficient").

45. See The Future of IT: Technology Visiting Committee Issues Report, MASs.GOv, https://www.mass. gov/courts/features/july-aug-2016-it-corner.html (last visited Apr. 6, 2017) [https://perma.cc/UD3P-8KTG] (summarizing pilot electronic data system). In Massachusetts, the pilot Electronic Application for Criminal Complaint (EACC) allows information to be shared between law enforcement agencies and the court case management system. Id. Common databases that aggregate limited data sets from multiple entities are similarly narrow in scope. See generally Brittany R. Fuller et al., Data Integration for the Thomas Jefferson Area Community Criminal Justice System, Sys. \& Info. EngineERING Design Symp. 300 (2014) (explaining pilot project in Virginia). The project took exported data from current systems and integrated them into a single relational database with a Microsoft SharePoint interface. Id.

46. Success Stories, NIEM, https://www.niem.gov/about-niem/success-stories (last visited Apr. 6, 2017) [https://perma.cc/P4S9-Q3DF] (highlighting Kansas, Florida, and Colorado court systems); see also Technology Tools, NAT'L CTR. FOR ST. CTS., http://www.ncsc.org/Services-and-Experts/Technology-tools.aspx (last visited Apr. 6, 2017) [https://perma.cc/KCW8-VJ9V] (listing number of services by NCSC related to use 
opportunity for courts to play a leadership role in improving such standards. ${ }^{47}$

The Massachusetts Trial Court recently sought recommendations from an ad hoc Visiting Committee on Technology that included chief information officers from Harvard University and the Massachusetts Institute of Technology. ${ }^{48}$ The Visiting Committee was tasked with making recommendations for improving the use of information technology within the court system. In their 2016 report, the Visiting Committee's recommendation to "[i]mprove data sharing and integration across systems," suggested that the Massachusetts courts "align with external stakeholders around what data formats and standards should be adopted to make interfaces more efficient by reducing the amount of unstructured data that is transmitted." 49

The lack of clear data standards impedes innovation by increasing the cost of development and limiting the population of potential users. Standards rarely develop from whole cloth. Rather they are often the result of custom, the outgrowth of de facto standards put in place by monopolistic parties. The standard is what people use. What do people use? The standard. For example, Microsoft Word is a de facto standard, as much as it hurts users of WordPerfect to admit it. GTFS is a standard in part because of Google's market dominance. $^{50}$ Eventually, robust legal data standards will arise. The question is who will control them. Given the courts' traditional role as arbiter of form, it seems appropriate that they should take a leading role. In so doing, they could likely accelerate innovation and shrink the justice gap. ${ }^{51}$

\section{THE CURRENT LANDSCAPE}

In addition to the courts' roles as keepers of records and arbiters of form,

of standards).

47. Legal aid providers and other stakeholders are taking initial steps to develop data standards to enable organizations in the civil justice system to share online platforms and data with one another. See, e.g., Kimberly Sanchez, The Florida Legal Resource Directory Project, OPEN REFERRAL (Dec. 22, 2016), https://openreferral.org/the-florida-legal-resource-directory-project [https://perma.cc/N7TS-GYDR] (creating data standards for legal and social service organizations); Welcome to Open Referral, OPEN REFERRAL, https://openreferral.org (last visited Apr. 6, 2017) [https://perma.cc/J584-P7ZQ] (highlighting use of data to help find community resources); OASIS Litigant Portal (LP) Technical Committee, OASIS, https://www.oasisopen.org/committees/lp/charter.php (last visited Apr. 6, 2017) [https://perma.cc/PPQ3-M25B] (seeking participants in technical committee to design litigant triage portal for legal services).

48. See Harvard Univ. Info. Tech., Report of the Massachusetts Court Technology Visiting COMMITTEE 2-3 (2016), http://www.mass.gov/courts/docs/bulletins/visting-committee-report-final-6-17-16.pdf [https://perma.cc/FC8A-Y9WP] (highlighting key findings in information technology).

49. Id. at 7 (referencing using application programming interfaces to integrate data sets across organizations).

50. See McHugh, supra note 22, at 125-34 (describing the history of GTFS).

51. See Alan Houseman, The Justice Gap, in Center for Am. Progress, Closing the Justice Gap: How InNovation And Evidence Can Bring Legal Services to More Americans 21, 21 (2011), https://cdn.americanprogress.org/wp-content/uploads/issues/2011/06/pdf/prose_all.pdf [https://perma.cc/QX2W -E9RT] (emphasizing justice gap where "less than 20 percent of low-income Americans' legal needs [are] met"). 
courts have a vested interest in the development of judicial data standards. State trial courts stand to benefit from setting the path by which they could link court data to other data sets and, perhaps more importantly, other resources to assist court users. ${ }^{52}$

\section{A. Access to Justice and the Role of the State Trial Court}

More and more people are coming to court without a lawyer. In areas from family law, to housing, to consumer debt, courts across the country have documented this development for several decades, with a marked increase since the 2007-2008 economic recession. ${ }^{53}$ Absent recognition of a legal right to counsel in civil matters, the primary reason that litigants navigate the civil legal system without an attorney is that they cannot afford to hire one. ${ }^{54}$ Legal aid programs that serve those with low incomes are under-resourced and operate under funding restrictions that prevent them from serving entire categories of users or legal issues. ${ }^{55}$ At the same time, attorneys in small and solo practice

52. The authors wrestled with the appropriate term for describing non-court actors interacting with the court, and although several identifiers were considered, the term "user" is the most inclusive. It is important to remember that users are people, not numbers. This is a core insight of user-centered design - a philosophy we endorse here.

53. See Legal Serv. Corp., Documenting the Justice Gap in America: The Current Unmet CiviL LEGAL NEEDS OF LOW-INCOME AMERICANS 5-7 (Sept. 2009), http://www.lsc.gov/sites/default/files/LSC/pdfs/ documenting_the_justice_gap_in_america_2009.pdf [https://perma.cc/3CU8-Z3Q2] (discussing legal issues arising from financial crisis); John M. Greacen, Self Represented Litigants and Court and Legal Services Responses to Their Needs: What We Know 3-6 (2003), http://www.courts.ca.gov/partners/documents/SRL whatweknow.pdf [https://perma.cc/9V6J-WV3G] (outlining research toward self-representation); Emily Savner, Expand Legal Services Now, NAT'L L.J. (June 28, 2010), http://www.brennancenter.org/blog/expandlegal-services-now [https://perma.cc/BMZ9-T4EX] (reporting increases in demand for legal services); Jonathan D. Glater, In a Downturn, More Act As Their Own Lawyers, N.Y. TIMES (Apr. 9, 2009), http://www.nytimes.com/2009/04/10/business/10lawyer.html [https://perma.cc/8KJN-DH36] (illustrating increase in pro se litigants).

54. See Jessica K. Steinberg, Demand Side Reform in the Poor People's Court, 47 ConN. L. REV. 741, 752 (2015) (addressing survey results showing increase in pro se litigation). In examining the characteristics of pro se litigants, studies have shown that "poverty is the primary force driving individuals to represent themselves in court." Id.; see also AM. BAR Ass'N., REPORT to THE House OF DelegAtes 4-5 (2006), www.americanbar.org/content/dam/aba/administrative/legal_aid_indigent_defendants/ls_sclaid_06A112A.auth checkdam.pdf [https://perma.cc/G6DQ-CG6K] (recognizing need for increase in counsel access for lowincome litigants); Laura K. Abel, A Right to Counsel in Civil Cases: Lessons from Gideon v. Wainwright, 15 TEMP. PoL. \& CiV. RTS. L. REV. 527, 529-30 (2006) (focusing on scope of proposed civil right to counsel); Paul Marvy \& Laura Klein Abel, Current Developments in Advocacy to Expand the Civil Right to Counsel, 25 Touro L. REV. 131, 132-33 (2009) (describing current efforts to address civil legal needs); John Pollock \& Michael S. Greco, It's Not Triage if the Patient Bleeds Out, 161 U. PA. L. REv. 40, 40-41 (2012) (affirming need to address civil legal aid needs); see also Sargent Shriver Civil Counsel Act, CAL. CTS., www.courts.ca.gov/15583.htm (last visited Apr. 6, 2017) [https://perma.cc/43T7-J7WJ] (explaining pilot program aimed at increasing counsel services for low-income civil litigants).

55. See Bos. Bar Ass'N, Statewide TASkforce to EXPAnd Civil Legal Aid in Mass., Investing IN JUSTICE 1 (2014), http://www.bostonbar.org/docs/default-document-library/statewide-task-force-to-expandcivil-legal-aid-in-ma---investing-in-justice.pdf [https://perma.cc/4C9K-WSSB] (suggesting most needy Massachusetts litigants denied access to justice). "In Massachusetts, civil legal aid programs turn away $64 \%$ of all eligible cases." Id. 
are struggling to build robust practices and connect with clients who can afford to pay for traditional representation. ${ }^{56}$

Scholars commonly refer to this phenomenon as the justice gap - the dual problem of too many low and moderate-income individuals who are unable to find or afford an attorney to assist with a legal problem, and the increasing number of attorneys who are unable to find sustainable legal work. ${ }^{57}$ As Access to Justice Advisor and Massachusetts Housing Court Judge Dina Fein notes, "[t]hese trends ... have converged to create a crisis that impacts all elements of the civil justice system, places untenable stress on the courts, and take an enormous toll on individuals, families, and society at large. ${ }^{, 58}$ In the absence of sufficient funding for legal aid or an affirmative right to counsel in most civil matters, alternative forms of assistance along a continuum for those without access to traditional full representation are necessary. ${ }^{59}$

The court system is a critical actor in addressing challenges facing the civil justice system, particularly for low and moderate-income litigants. ${ }^{60}$ Courts recognize their responsibility to address the needs of court users, as well as would-be court users, which consist of both those who do not or cannot use the

56. See Russell Engler, Access to Justice and the Role of the Private Practitioner, 24 KAN. J.L. \& PuB. POL'Y 554, 567-69 (2015) (describing how private practitioners can generate fees while also addressing justice gap). See generally Deborah L. Rhode, Access to Justice: A Roadmap for Reform, 41 FordHAM URB. L.J. 1227 (2014) (suggesting financial reforms to civil justice system).

57. Houseman, supra note 51, at 21 (defining the justice gap).

58. Hon. Dina Fein, Access to Justice: A Call for Progress, 39 W. New Eng. L. REv. (forthcoming 2017).

59. See Jennifer M. Smith, Rationed Justice, 49 SufFolk U. L. REv. 353, 365 (2016) (noting need for civil legal aid funding). The lack of funding creates a need for creative, low-cost solutions. See Russell Engler, Towards a Context-Based Civil Right to Counsel Through "Access to Justice" Initiatives, 40 ClEARINGHOUSE REV. 196, 200 (2006) (expounding on importance of measuring efficacy of new solutions); Steve EpplerEpstein, The Fight for Legal Aid Funding and Right to Counsel Advocacy: An Incremental Approach and an Overarching Message, 26 Mgmt. INFo. Exchange J. 41, $43-44$ (2012) (proposing alternative forms of assistance for low-income clients).

60. See Richard SusSKind, TOMORRow's LaWyers: An InTROduction to Your Future 84-91 (2013) [hereinafter SUSSKIND, TOMORROW'S LAWYERS] (emphasizing importance of access to justice initiatives in future legal landscape). Since the 1990s, court administration experts were predicting a dramatic shift in the way courts do business because of technological innovation. See RICHARD SuSSKIND, THE END OF LAWYERS?: Rethinking the Nature of Legal Services 185 (2008); see also Hon. Paul J. De Muniz, Building Tomorrow's Courts Today, in NAT'L CTR. FOR STATE CourTs, Future TRENDS IN STATE CourTs 82, 82 (2009) (discussing Oregon court system's goals and strategic plans), http://www.ndcrc.org/sites/default/files /future_trends_2009.pdf [https://perma.cc/69M6-VMCU]; Joseph F. Coates, Law and Technology in the Twenty-First Century, 52 TECH. FORECASTING \& SOC. CHANGE 255, 259-60 (1996) (describing potential legal and technological issues with twenty-first century technology); Jim Dator, When Courts Are Overgrown with Grass: The Role of Courts in the 21st Century, 32 FUTURES 183, 189 (2000) (describing societal change's impact on legal services); Sohail Inayatullah, The Future of State Court Administration, FUTURES RES. Q. 5, 16 (1986), http://www.metafuture.org/library1/JudiciaryFutures/future-of-state-court-administration-frq-1994.pdf (discussing changes in court administration); Hon. R.B. "Chips" Shore et al., The ROI of Emerging Technologies, NAT'L CTR. FOR ST. CTS., http://cdm16501.contentdm.oclc.org/cdm/singleitem/collection /accessfair/id/209/rec/1 (last visited Apr. 6, 2017) [https://perma.cc/E2YB-CCHT] (offering presentation on technological innovation in Florida courts). 
courts to address justiciable legal questions, as well as those who are not engaging in the system despite having active cases within the courts. Leaders of state judiciaries emphasize the need to work across organizations to implement common policy solutions. Yet these state leaders face institutional and cultural barriers to some of the solutions they seek.

Institutional inertia presents perhaps the greatest challenge. ${ }^{61}$ State court systems are slow to change, even when court leaders recognize that change is needed. $^{62}$ For example, people who enter the courts with civil legal problems and without representation often struggle with complex court procedures. ${ }^{63}$ Antiquated court procedures require additional explanation and instruction, for attorneys and parties alike. ${ }^{64}$ Courts have the power to simplify court processes themselves. ${ }^{65}$ Civil procedure rules in most jurisdictions require service of process by publication in newspapers after failed attempts to locate the defendant. However, it is a well-recognized fact that a potentially interested party will rarely ever have actual notice by reading the newspaper. While these specific procedures are largely unchanged, the tide is turning in favor of greater access and better resources provided by courts to court users. ${ }^{66}$ In Turner $v$. Rogers,${ }^{67}$ the Supreme Court held safeguards are required to ensure that courts do not "risk ... erroneous deprivation of liberty." of Turner, more and more courts have adopted plain language court forms and instructions, explanations of court processes, and other written self-help tools. ${ }^{69}$

61. See Russell Engler, And Justice for All-Including the Unrepresented Poor: Revisiting the Roles of the Judges, Mediators, and Clerks, 67 FORDHAM L. REV. 1987, 2022-23 (1999) (noting changes to court rules to help promote fairness and justice). But see John M. Greacen, Legal Information vs. Legal Advice: Developments During the Last Five Years, 84 JUdicATURE 198, 203 (2001) (arguing courts can address imbalance without modifying current rules).

62. See Bruce Tonn et al., Future of the Courts: Fixed, Flexible, and Improvisational Frameworks, 44 FUTURES 802,810 (2012) (noting "[w]e must anticipate and address potential resistance to changes to the court system").

63. See Steinberg, supra note 54, at 755-56 (discussing problematic errors pro se litigants make and threats judicial process imposes on them).

64. See id. at 754 (describing "complex, and often counter-intuitive, procedures").

65. See Richard Zorza, Some First Thoughts on Court Simplification: The Key to Civil Access and Justice Transformation, 61 DRAKE L. REV. 845, 863-64 (2013) (asserting procedural simplification will lead to substantive simplification of current complex system).

66. See Instructions for Alternate Service, ALASKA.GOV, http://courts.alaska.gov/shc/family/shc-184.htm (last visited Apr. 6, 2017) [https://perma.cc/9R2V-H4KS] (permitting alternate website service and other alternate means after "diligent inquiry" to find defendants).

67. 564 U.S. 431 (2011).

68. Id. at 477; see also Model CODE OF Judicial CONDUCt R. 2.2 (2007) (noting fairness obligation).

69. See Laura K. Abel, Turner v. Rogers and the Right of Meaningful Access to the Courts, 89 DENV. U. L. REv. 805, 807 (2012) (describing Turner-mandated assistance); Russell Engler, Turner v. Rogers and the Essential Role of the Courts in Delivering Access to Justice, 7 HARV. L. \& POL'Y REv. 31, 36 (2013) (documenting increase in access to justice initiatives); Richard Zorza, Turner v. Rogers: The Implications for Access to Justice Strategies, 95 JUdiCATURE 255, 257-58 (2012) (exploring what program mandates Turner requires). Instructions that accompany court forms are moving toward lower reading levels and increased "plain language" use. Plain Writing Act of 2010, Pub. L. No. 111-274, 124 Stat. 2861 (2010) (noting "[t]he 
However, self-help tools are generally developed internally by courts themselves without input or contributions from court users, be they litigants or attorneys. Courts avoid providing legal advice or sharing information developed by advocates in order to preserve the appearance of judicial neutrality. The unfortunate consequence of a reliance on judicial neutrality, on the other hand, is that the court can tend to play a passive role, at times arguably acting as a rubber stamp for the most powerful actor. This is endemic to both individual judges in individual courtrooms, as well as court administrators overall. $^{70}$ As a result, even where another institution has developed explanatory self-help tools, courts develop their own. These err on the side of neutrality at the expense of targeted information or connections between vulnerable populations and legal services providers who can serve their needs.

\section{B. Technology, Access to Justice, and the Courts: Current Practice}

As the Conference of Chief Justices and Conference of State Court Administrators highlighted in its 2015 joint resolution, Reaffirming the Commitment to Meaningful Access to Justice for All, "effective use of technology" is a great tool for expanding access to justice. ${ }^{71}$ Private practitioners, technology entrepreneurs, and legal aid organizations have all begun to take advantage of technology to address the justice gap. For example, the Legal Services Corporation's Technology Innovation Grants (TIGs) incentivize legal aid organizations to use technology to increase legal service organizations' efficiency and effectiveness. ${ }^{72}$ TIGs are largely hailed as a

purpose of this Act is to improve effectiveness and accountability of Federal Agencies"). Courts are encouraged to adopt the principles of the Plain Writing Act of 2010, which requires all federal agencies to use "clear Government communication that the public can understand and use." Id.

70. See Russell Engler, Ethics in Transition: Unrepresented Litigants and the Changing Judicial Role, 22 Notre DAme J.L. ETHICS \& PUB. POL'Y 367, 387-88 (2008) (noting criticism of passive judiciary with pro se litigants); Richard Zorza, The Disconnect Between the Requirements of Judicial Neutrality and Those of the Appearance of Neutrality When Parties Appear Pro Se: Causes, Solutions, Recommendations, and Implications, 17 GEO. J. LEGAL ETHICs 423, 429-30 (2004) (analyzing how judges assist pro se litigants and maintain neutrality simultaneously); see also Rebecca A. Albrecht et al., Judicial Techniques for Cases Involving Self-Represented Litigants, 42 JUDGES' J. 16, 16-17 (2003) (surveying case law for techniques for adjudicating cases with pro se litigants); Paula Hannaford-Agor, Helping the Pro Se Litigant: A Changing Landscape, 39 CT. REV. 8, 14-15 (2003) (positing "collaboration for seamless access to justice" for pro se litigants).

71. See Conference of Chief Justices and Conference of State Court Administrators Resolution 5: Reaffirming the Commitment to Meaningful Access to Justice for All, NAT'L CTR. FOR ST. CTS. (2015), http://www.ncsc.org/ /media/Microsites/Files/CCJ/Resolutions/07252015-Reaffirming-Commitment-

Meaningful-Access-to-Justice-for-All.ashx [https://perma.cc/46QC-YP7F] (noting advancements in creating access to effective assistance of counsel). The Resolution cites several new initiatives, many of which are covered in this Article, including "expanded self-help services to litigants, new or modified court rules and processes that facilitate access, discrete task representation by counsel, increased pro bono assistance, effective use of technology . . . and triage models to match specific needs to the appropriate level of services." Id.

72. Technology Initiative Grant Program, LEGAL SERvs. CORP., http://www.lsc.gov/grants-grantee- 
success, but unfortunately, they have few analogues in the courts. ${ }^{73}$

At the same time, court systems are improving technology by leaps and bounds. Much in the same way developing countries skipped over landline telephones entirely - going from no telephone access directly to cell phonesstate court systems in many jurisdictions are "leapfrogging" over some of the technological advancements of the 1990s and early 2000s, and some are literally moving directly from the typewriter to electronic completion and submission of court documents. ${ }^{74}$ State court technological improvements include court websites, electronically accessible court forms, information, and multimedia self-help tools, electronic filing of court pleadings, and electronic access to court records.

Adding new technologies to a court system's repertoire necessarily means some changes to court operations. One of the reasons we do not see a more significant transformation in court operations or user experience is the way that technology is adopted by the courts. New tools are often grafted onto existing business practices, resulting in redundant and duplicative resources, information, and technologies. Much of the effort to improve internal court technology has not been linked conceptually to the needs of outside users. Most court technology focuses solely on the court's needs instead of an outside user's legal and informational needs.

Web-based information sharing is one clear example. Courts and courtbased law libraries have progressed beyond initial concerns about the unauthorized practice of law when providing legal information online. ${ }^{75}$ Almost all state courts have some form of court website that includes information about different courthouses and legal topics. There are clear benefits to the advent of these sites, including a trend toward responsive, mobile-friendly design and other improvements to render court information easier to find, navigate, and absorb. While those improvements are laudable, court web tools are lacking in two key areas. First, they are typically organized from the court's organizational perspective, rather than from the perspective of the target audience. Second, they are largely redundant of other efforts. Courts are generally reluctant to collaborate with perceived advocacy organizations,

resources/our-grant-programs/tig (last visited Apr. 6, 2017) [https://perma.cc/N5KS-LPNF] (providing overview of TIG eligibility requirements and applicable law).

73. See Technology Initiative Grant Highlights and Impact, Legal Servs. CorP., http://www.lsc.gov/ grants-grantee-resources/our-grant-programs/technology-initiative-grant-program/technology (last visited Apr. 6 , 2017) [https://perma.cc/6F87-S97D] (describing successful programs utilizing TIG to enhance access).

74. See Richard T. Watson, Africa's Contributions to Information Systems, 5 African J. INFO. Sys. 126, 128 (2013) ("Mobile phone technology, fortunately, enabled African countries to leapfrog landline technology and install the cheaper and more useful cell phone system.").

75. See Clark, supra note 3, at 260-61 nn.79-83 (citing multiple court-based self-help websites); see also Ursula Gorham, Facilitating Access to Legal Information by Self-Represented Litigants: An Exploratory Case Study of the People's Law Library of Maryland, 2 J. OPEN ACCESS L. 1, 8 (2014) (examining Maryland law libraries' legal information practices through case study). 
resulting in duplicative content across the government and nonprofit sphere. At the same time, private entrepreneurs are far ahead of courts and legal services providers in developing web-based information and advertising. Litigants searching online for information about family law are far more likely to find a search engine-optimized site from an enterprising small law firm looking for new clients rather than either of the more neutral resources. ${ }^{76}$

Websites, text alerts, multimedia self-help, remote assistance, and electronic records are a sample of the various technologies that could have been a lever for improving access to the courts and access to justice overall. However, as interested groups introduced these initiatives, they were built to accommodate existing systems and not to challenge them. Further, rather than break down the silos between justice system stakeholders, new technologies have served to strengthen and entrench those separations.

\section{A Pay-to-Play Digital Future?}

The belief that a common vendor, not a common data standard, must be used in order to safeguard data quality is dangerous. It leads to the conclusion that one vendor must be given a monopoly over electronic processes. Earlier we imagined a court mandating all filings be typed on a 1939 Underwood No. 5 typewriter. Let us assume that in the end, they decided it was good enough to mandate all filings come on A1 paper with one-inch margins. After all, attorneys were starting to buy their own typewriters. They did, however, have lingering concerns over security. How could they be sure that a filing would make it safely from the typewriter to the court? So, the courts put out a bid asking for couriers. They received a healthy number of responses.

However, they all insisted on exclusive contracts. After all, common vendors are the safeguards of quality. The court chose the lowest bid and agreed to an exclusive contract. The next day an attorney arrived at the court with a filing only to find one of these couriers outside the clerk's office. She thought nothing of this and walked into the office to make her filing. However, the clerk informed her that she would have to have the filing delivered by the courier. She asked why, and was told it was the only way to guarantee security. She asked if she could just hand the filing over or send it certified mail, and was told, "No, it has to come via our courier service. No one else will do."

In the digital world, this is like allowing only one vendor to provide e-filing when it is technically possible to have a single vendor implement a standardsbased, not vendor-based, system that authorized vendors could access. You might think this absurd, and you might also assume that this is a metaphor.

76. A Google search for "family law" in Massachusetts in April 2017, for example, resulted in the following top ten search results: four law firm sites, three sites to find private attorneys, and zero sites from the court system or legal aid. The authors encourage the reader to conduct a search with the search engine and jurisdiction of their choice. 
However, if you attempted to make a civil filing in Montgomery County, Texas in 2010 , you were actually required to file electronically. ${ }^{77}$ In fact, you were required to make this filing through a single vendor, and you had to pay for the privilege above and beyond standard court fees. ${ }^{78}$ Thankfully, this arrangement is no longer in place in Montgomery County, although as of 2015, attorneys and possibly litigants in a few states are still locked into similar third-party vendor contracts. ${ }^{79}$ Currently, the Texas e-filing service offers a selection of filing providers, including free options. Yet when a court mistakenly conflates the need for a common vendor with the need for common standards, it distorts incentives. ${ }^{80}$ It moves the center of power towards vendors, distancing it from user-centered interests and exacerbating the justice gap by prioritizing the preferences of third-party vendors over litigants.

\section{The ReVOLUTION WILl BE STANDARDIZED: IMPROVING ON EXISTING TECH INNOVATIONS THROUGH DATA STANDARDS}

Technologies aiming to disrupt the legal system in the service of access to justice should share the following principles: (1) collaboration between courts and other justice system partners; (2) user-centered design; and (3) openness to change existing practices when the need for and efficacy of change is supported by evidence. This section addresses several court-based technological innovations that, if designed using the above principles, can leverage shared data to improve access to justice dramatically.

Going to court is no simple task. Imagine a world where you learn you have a legal problem in one office, then have to go to a different office to explain that problem and find out who can help you with that problem. Armed with

77. Courtney Minick, LexisTexas: Privatizing Access to Public Courts, Justia L. Blog (Feb. 4, 2011), https://lawblog.justia.com/2011/02/04/lexistexas-privatizing-access-to-public-courts [http://perma.cc/F7CP-UK DA] (explaining court order mandating electronic filing).

78. Id.

79. See District Clerk Implements New E-Filing System February 1, 2014!, MCTX, http://www.mctx.org/departments/departments_d_-_f/district_clerk/electronic_filing.php (last visited Apr. 6, 2017) [https://perma.cc/5A4B-JGZB] (noting "firms MUST select a certified electronic filing service provider"). Some jurisdictions appear to maintain the type of restrictive contract that Montgomery County ended. See R. Lainie Wilson Harris, Ready or Not Here We E-Come: Remaining Persuasive Amidst the Shift Towards Electronic Filing, 12 LEGAL COMM. \& RHETORIC: JAWLD 83, 90-107 (2015) (describing the status of each state's rules and vendors for electronic filing). Harris's survey of e-filing requirements across states seems to indicate that attorneys are required to use a single vendor for mandatory electronic filing of certain case types and locations within several jurisdictions. Arizona appellate courts have created AZTurboCourt, but it is not yet rolled out at trial level; Delaware has civil complaints using File \& Serve Xpress; and several courts, including Michigan pilot courts, several Minnesota districts, Oregon, and South Dakota, have adopted Tyler Technologies Odyssey File \& Serve. $I d$. at 91-93, 98, 103-04. In addition to third-party vendors, several states have developed their own in-house platforms that are the only option for complying with mandatory efiling: Colorado, New York, and Summit County Ohio. Id. at 92-93, 101-02.

80. See Minick, supra note 77 (noting Montgomery County received one dollar back from service provider per filing). 
that information, you go to a third office, explain what you have learned, and obtain some help filling out a court form. After getting help, you take that form to court. Then to look up what happens next in your case, you must return to the court or go to a different building altogether to see what happens next. For many low and moderate-income litigants navigating court processes, that is an accurate description of the steps they must take, with long periods of waiting on hold sprinkled in. From the legal technologist's perspective, the existing technology in the courts represents a replica of that inefficient and frustrating structure.

Two forms of technological solutions on the horizon may address this problem: tools to guide people through understanding their legal problems and connect them to resources, and for those already in the court system, tools to share information between court users and the courts. These technologies already exist, and some courts use them, as well as private attorneys and legal aid organizations. ${ }^{81}$ Their efficacy is limited by the lack of means for those tools to connect with one another. Data standards will be the first step towards truly leveraging this technology to revolutionize the relationship between courts, justice system partners, and court users themselves. Through data standards and data governance, courts have an opportunity to demolish existing silos and create an integrated system with a shared data infrastructure.

\section{A. Automated Tools: Triage and Expert Systems}

\section{Triage Explained}

Courts and attorneys engage in legal triage: assigning a level of service to a person based on available resources and the nature of their legal need. ${ }^{82}$ One of the challenges facing triage is how to look upstream, and provide information or points of entry into a decision-making system at an earlier stage in individual legal or quasi-legal questions. ${ }^{83}$ Many non-lawyers do not recognize when they are facing legal questions, misclassifying them as the subjects of some other

81. See Michael J. Wolf, Collaborative Technology Improves Access to Justice, 15 N.Y.U. J. LeGIS. \& PUB. POL'Y 759, 771 (2012) (outlining dispute resolution, document assembly, and other "collaborative" technology solutions benefitting pro se litigants); see also Stephanie Kimbro, Using Technology to Unbundle in the Legal Services Community, Harv. J.L. \& TeCh. OcCasional PAPER Series, 14-15 (2013) (remarking on how groups can unbundle legal services with help of technological innovation); supra note 47.

82. See Thomas M. Clarke \& Victor E. Flango, Case Triage for the 21st Century, in NAT'L CTR. FOR State Courts, Future Trends IN State CourTs 146, 146 (2012), http://www.ncsc.org (to access follow perma.cc link) [https://perma.cc/6N29-KD92] (noting "[c]ase pressure on courts and judges is steadily increasing over time").

83. See Ross C. Brownson et al., Measuring the Impact of Public Health Policy, 7 Preventing Chronic DISEASE 1, 1 (2010) (borrowing "upstream" terminology from public health literature). Upstream policy changes "affect large populations through regulation, increased access, or economic incentives" as opposed to "downstream" intervention that occurs on individual-level approaches. Id. 
domain. ${ }^{84}$ Triage is most effective for people in the "information-gathering" stage, the point when someone begins to search for answers to what attorneys would consider a legal question. ${ }^{85}$ In the private bar, this idea has taken the form of a "legal checkup" as a way to uncover the latent legal market. ${ }^{86} \mathrm{~A}$ legal checkup would provide an opportunity for would-be court users to assess their situations and possible paths for addressing their legal needs before reaching a crisis point. ${ }^{87}$

Technology-assisted triage is essentially the idea of an automated "sorting hat" that will connect people to the appropriate resource for their legal needs, without the need for an attorney. ${ }^{88}$ Automated triage is well positioned for those seeking answers. Individuals in the information-gathering stage first start with friends and family, or others in the community with a similar legal question or problem. After that, they take to the Internet. Here, a web-based automated triage tool can be accessed based on a user's expressed needs or the query that a person puts forth, reducing the burden of outreach and communication between service providers and those who would benefit from services.

Reaching users early in the process is only the first step in successful triage. The next step is assessment of a legal question, often the most difficult step for a non-lawyer. ${ }^{89}$ Interactive assessment has traditionally been the purview of attorneys exploring options with their client. The goal of technology-assisted triage is for the user to procure a similar assessment through automated tools.

\section{Improving Triage Through Data Standards}

Most triage systems across the civil legal justice community are fragmented - at a minimum, walling off the court system from the rest of the legal community. ${ }^{90}$ At the same time, multiple entities develop overlapping

84. See Rebecca L. Sandefur, What We Know and Need to Know About the Legal Needs of the Public, 67 S.C. L. REv. 443, 443-44 (2016) (highlighting obstacles for obtaining legal aid early on in process).

85. See Am. Bar Ass'N, Report on the Future of Legal Services 43-44 (Aug. 2016), http://www.americanbar.org/content/dam/aba/images/abanews/2016FLSReport_FNL_WEB.pdf [https://perma .cc/9F7Q-87H7] (recommending "legal checkup" concept).

86. See id. at 43 (noting "legal checkups are an underused resource").

87. See id; see also SUSSKIND, TOMORROW's LAWYERS, supra note 60, at 91 (discussing how technology can aid lawyers to assist "latent legal market").

88. See Richard Zorza, The Access to Justice "Sorting Hat": Towards a System of Triage and Intake that Maximizes Access and Outcomes, 89 DENV. U. L. Rev. 859, $874-75$ (2012) (providing new triage model for legal aid).

89. See Richard Zorza, Nat'l Ctr for St. Cts., The Self-Help Friendly Court: Designed From THE GROUND UP TO WORK FOR PEOPLE Without LAWYeRs 17-18 (2002), http://www.zorza.net/Res_ProSe_ SelfHelpCtPub.pdf [https://perma.cc/T498-BE3N] (pointing out specific hurdles for pro se litigants).

90. See Rebecca L. SANDefur \& Aaron C. SMYth, Am. Bar Found., Access Across America: First Report of the Civil Justice Infrastructure Mapping Project ix (2011), http://www.americanbar foundation.org/uploads/cms/documents/access_across_america_first_report_of_the_civil_justice_infrastructure _mapping_project.pdf [https://perma.cc/V9M8-QH45] (providing comprehensive research on status of state 
(and competing) websites to answer questions and direct users to specific resources.

[F]or triage to be successful on a systemic level, stakeholders cannot continue independently to design and deploy triage systems for litigants. By definition, a litigant portal requires coordination between the courts, and the legal and non-legal service providers because litigant users will want these portals to provide access to legal and practical information. ${ }^{91}$

In 2016, the Legal Services Corporation (LSC) and Microsoft announced a pilot to develop a statewide, single triage portal. ${ }^{92}$ The vision for this statewide triage portal takes users from initial information gathering, through assessment and decision-making, and ultimately connects them to the applicable legal resource, be it intake for a legal service provider, application for a government service, or electronic filing of a legal pleading. ${ }^{93}$ The LSC-Microsoft Request for Proposals is remarkably ambitious in scope, but even that pilot does not explicitly address integrating existing information systems. ${ }^{94}$ Standards and governance structures for data sharing are a necessary foundation for technology-assisted triage.

Data standards themselves will improve the quality of technology-assisted triage, primarily by reducing inefficiencies. The current experience of verbally or manually providing the same information repeatedly is inefficient for everyone involved, and can re-traumatize those users in crisis. Whether it is the court or another actor, in order to share data across entities, someone will have to set standards that parties adopt and utilize. The absence of standards

civil legal aid infrastructure). "The results [of the research] are sobering. They underscore a fundamental absence of coordination in the system, fragmentation and inequality in who gets served and how, and arbitrariness in access to justice depending on where one lives." Id. (emphasizing gravity of authors' findings).

91. Tom Clarke et al., State Justice Inst. \& Nat’l Ctr. for State Courts, Triage Protocols for litigant Portals: A Coordinated Strategy Between Courts and Service Providers 2 (2013), http://www.srln.org/system/files/attachments/Triage_Protocols_for_Litigant_Portals_A_Coordinated_Strategy _Between_Courts_and_Service_Providers.pdf [https://perma.cc/F5X5-RVY5].

92. See Legal Services Corp., Request for Proposals: Microsoft Statewide Access Portal PROJECT 2-3, http://lsc.gov/sites/default/files/attach/2016/11/MS-statesidePortalProject.pdf (last visited Apr. 6, 2017) [https://perma.cc/7R8Y-8Q9K] [hereinafter REQUEST FOR PROPOSALS] (announcing project and requesting proposals).

93. See generally Thomas M. Clarke, State Justice Inst. \& Nat’h Ctr. for State Courts, BuILding A Litigant PORTAL: Business AND TECHNICAL REQUiREMENTS (2015), http://www.srln.org/system/ files/attachments/Report\%20Building\%20a\%20Litigant\%20Portal\%20\%28Clarke\%202015\%29.pdf

(discussing various strategic goals). This is an expansive and aspirational view of triage. Id. at 1-3 (providing vision for statewide triage portal). While private entities like Avvo and nonprofits like the American Bar Association Free Legal Answers Initiative begin to connect individuals with legal questions to answers and attorneys, for the most part, a direct connection between the initial search and the ultimate resource still does not exist. See Request For Proposals, supra note 92, at 3 (describing the current "complex patchwork of services").

94. See generally REQUEST FOR PROPOSALS, supra note 92 (failing to mention integration of existing systems). 
ensures that technology-assisted triage serves only to connect people to services, missing an opportunity to eliminate duplicate data entry on the part of users.

Building data-sharing infrastructure also serves the purpose of bringing the various stakeholders together. State courts are newcomers to the world of algorithmically-mediated triage, but they wield tremendous power to enhance the success of these efforts. By establishing a structure for sharing data, courts will have the opportunity to start the conversation across the legal system. In order for an automated triage tool to reflect the input of legal aid, the private bar, the judiciary, and administrative and social service agencies must be able to share data with one another. The courts are well positioned to facilitate these conversations.

Triage portals like the one contemplated in the LSC and Microsoft pilot go beyond the diagnosis of a legal problem toward "guid[ing] self-represented litigants through the entire legal process." ${ }^{.95}$ Courts that adopt data standards and APIs will have the added benefit of enabling controlled access to their own case management systems, allowing for electronic filing directly from the triage portal. ${ }^{96}$ This reduction in transaction costs can serve as the fuel for enumerable innovations.

\section{B. Data Sharing Through e-Filing, Case Management Systems, and Electronic Records}

First federal courts, and now state courts, have added the option - and in some cases, the requirement—of electronically filing court documents. ${ }^{97}$ Many courts have added this feature to their existing workflow without ensuring that the new technologies communicate with the old. The information in electronically filed documents cannot necessarily be imported into legacy systems. Consequently, many courts find themselves entering data manually into multiple systems. In some jurisdictions, for example, parties must still make paper filings that are electronically scanned later. ${ }^{98}$ In order to facilitate information sharing among parties, some courts require that orders and other forms must be printed or typed via typewriter onto carbon or carbonless copy

95. Id. at 3 .

96. See id. (explaining component of integrated service delivery system).

97. See Harris, supra note 79, at 89 n.36 (listing thirty-one states requiring e-filing in at least some case types); see also Timothy A. Gudas, E-Filing in State Appellate Courts: An Updated Appraisal 2-4 (Sept. 2014), http://www.appellatecourtclerks.org/publications-reports/docs/NCACC_E-Filing_White_PaperSeptem ber2014.pdf [https://perma.cc/N4UH-4GH9] (describing origins of federal court electronic filing).

98. See Lynne Marek, Patchwork E-Filing Frustrates Lawyers, NAT'L L.J. (Feb. 26, 2008), http://www.nationallawjournal.com/id=900005504188/Patchwork-EFiling-Frustrates-Lawyers [https://perma.cc/47CS-BZ8T] (noting Cook County filing issues). Cf. Ben Farrell, Note, Spoliation in a Digital World: Proposing a New Standard of Culpability in Massachusetts for an Adverse Inference Instruction, 14 SUFFOLK J. TRIAL \& APP. ADVOC. 110, 112 (2009) (suggesting court treat electronic discovery documents the same way they treat paper discovery documents). 
paper: the white original for the court, pink for the initiating party, yellow for the responding party, etc. In several cases-including domestic violence restraining orders - courts rely on this method for copying information despite it being difficult to read and edit.

Interactive tools assist litigants with clarifying their legal issue and populating applicable court forms with relevant information as one unit. These interactive tools include expert systems, ${ }^{99}$ guided interviews (also called guided walkthroughs), ${ }^{100}$ and document assembly programs. ${ }^{101}$ When combined, these tools effectively develop an interface that assists users with a range of tasks, from decision-making to completion of court forms. ${ }^{102}$

Far more than electronically fillable forms, guided interviews help individuals through the procedural steps and key decision points in a legal question. ${ }^{103}$ By eliciting only responses relevant to the specific legal issue, guided interviews populate necessary forms and reduce incorrect or inaccurate information. ${ }^{104}$ Guided interviews can assist litigants in navigating complex court processes through limited decision trees, without requiring in-person assistance. ${ }^{105}$ They act as an automated intermediary, providing information relevant to the user in order to generate responses relevant to the court.

These automated tools face the same challenge that we see in other technological interventions: lack of uniformity and fragmentation of civil

99. See Randall Davis, Amplifying Expertise with Expert Systems, in THE AI BusInEss: THE Commercial Uses of Artificial Intelligence 17, 18-19 (Patrick H. Winston \& Karen A. Prendergast eds., 1984) (characterizing expert systems).

100. See Kimbro, supra note 81, at 22 (defining guided walkthroughs).

101. See Claudia Johnson, Online Document Assembly Initiatives to Aid the Self-Represented, in InNOVATIONS For Self-RePReSENTEd Litigants 97, 97-98 (Bonnie Rose Hough \& Pamela Cardullo Ortiz eds., 2011) (defining online document assembly); see also Deborah SAUNDERS ET AL., CTR. ON CourT Access to Justice FOR All, Access Brief: Forms AND DOCUMEnt Assembly 2-3 (2012), http://ncsc.contentdm.oclc.org/utils/getfile/collection/accessfair/id/264/filename/265.pdf [https://perma.cc/3R7 A-TETS] (describing how to provide clearly-written forms for common procedures). The notion that document assembly could "transform the legal profession" originated in the 1970s. See Ronald W. Staudt, All the Wild Possibilities: Technology That Attacks Barriers to Access to Justice, 42 Loy. L.A. L. REV. 1117, 1122 \& n.18 (2009) (citing James A. Sprowl, Developing Computerized Practice Aids for Tomorrow's Law Practice, 12 LEGAL ECON. 37, 44 (1986)).

102. See Ronald W. Staudt \& Andrew P. Medeiros, Access to Justice and Technology Clinics: A 4\% Solution, 88 ChI.-Kent L. REv. 695, 708-09 (2013) (discussing easy-to-use features of guided interview interfaces).

103. See Phil Malone et al., Berkman Klein Ctr. for Internet \& Soc'y at Harvard Univ., Preliminary Report: Best Practices in the Use of Technology to Facilitate Access to Justice INITIATIVES 24 (2010), http://cyber.harvard.edu/sites/cyber.harvard.edu/files/A2J_Report_Final_073010.pdf [https://perma.cc/T3G5-XKBQ] (providing overview of guided interview process and benefits, including use of automated interviews).

104. See Rochelle Klempner, The Case for Court-Based Document Assembly Programs: A Review of the New York State Court System's "DIY” Forms, 41 FordHAM URB. L.J. 1189, 1193 (2014) (describing New York court system use of A2J-Author-guided interviews).

105. See Kimbro, supra note 81, at 22 (considering guided interview system useful self-help tool). 
justice system stakeholder efforts. ${ }^{106}$ Legal services providers and courts use their own platforms for developing these tools, which are generally standalone and do not connect with other systems. A guided interview that results in document preparation will be most effective if the data obtained can be shared directly with the court's case management system through electronic filing. A few courts have begun to connect guided interviews and document assembly programs to electronic filing, often through proprietary arrangements with single vendors. ${ }^{107}$ This can lead to stagnant or obsolete technology platforms due to vendor lock-in and institutional inertia. ${ }^{108}$

By connecting the e-filing mechanism to a user-centered interface that includes interactive information and decision-making tools, courts can move away from thinking of e-filing as simply another mode of submission. Open data standards permit multiple actors to develop user interfaces that can link users to the courts, similar to the public transit examples discussed earlier, fostering competition that will ultimately improve the available products and reduce the burden on the court to develop bespoke tools.

Despite occupying two sides of the same coin, input/writing and output/reading, electronic filing is often disconnected from electronic access to court records. Public availability of court records has moved online on a separate path from the development of electronic filing. Adopting electronic filing has been a slow, deliberative process, as jurisdictions weigh the effects of changing civil procedure. ${ }^{109}$ Electronic sharing of court records, on the other hand, has been largely driven by considerations of technical capacity.

It is now technically feasible to make any electronically stored court information available to the public, ranging from case numbers and party names to court dates, and the pleadings themselves. Jurisdictions across the country have found themselves in the uncomfortable position of having unintentionally made too much information available to the public online, enabling credit reporting agencies, employers, landlords, and others to use court data for improper purposes. ${ }^{110}$ At the same time, with very few

106. See James E. Cabral et al., Using Technology to Enhance Access to Justice, 26 HARV. J.L. \& TECH. 241, 306, 323 (2012) (evaluating barriers to technological progress).

107. See Klempner, supra note 104, at 1193 (explaining success of New York City's DIY forms).

108. See Leila Atassi, Court Administrators Say Suspicious Contract Caused Court Reform Delays, BLog. CLEVELAND (Jan. 4, 2010), http://blog.cleveland.com/metro/2009/12/court_administrators_say_suspi.html [https://perma.cc/QAM3-E56K] (recognizing, for example, challenges to implementing proprietary software in Ohio led to delays).

109. See generally James E. McMillan et al., Nat’L Ctr. for State Courts, A Guidebook for ELECTRONIC COURT FILING (1998), http://www.srln.org/system/files/attachments/A_Guidebook_for_Electronic _Court_Filing.pdf [https://perma.cc/7SLL-HEQ5] (discussing policy and practice considerations for initiating electronic filing). The federal courts' Public Access to Court Electronic Records (PACER) system is an exception because it combines e-filing and electronic access to records-PACER makes each case's docket sheet and substantive pleadings available to the parties and the public. See PACER, https://www.pacer.gov (last visited Apr. 6, 2017) [https://perma.cc/9ZXQ-9YPH].

110. See Rudy Kleysteuber, Note, Tenant Screening Thirty Years Later: A Statutory Proposal to Protect 
exceptions, courts have not developed systems to enable litigants to see details of their own cases. ${ }^{111}$

While electronic filing and electronic court records were not universally developed with litigants in mind, they can be adapted to meet litigants' needs. ${ }^{112}$ By establishing and committing to data standards, courts can build connections across entities. They can integrate systems so that an individual will be able to go seamlessly from information-gathering through legal guidance to electronic submission of court pleadings without waiting in line, manually or verbally re-explaining her legal situation, or falling through the cracks.

With the capacity to move through each step in the court process online, why have a physical courthouse? The American Bar Association and other groups have embraced online dispute resolution (ODR), perhaps the most extreme example of legal technological disruption of the court system. ${ }^{113}$ Leaving aside the policy discussion of whether they are viable or desirable, ODR platforms will be most effective when all entities involved can share information with one another through a common language. ${ }^{114}$

\section{BuILDing ON A CUlture of DATA SHARING TO AID THE 100\% ACCESS MOVEMENT}

The previous Section described tools that would generate shared information and communication between courts, legal aid organizations, other government entities, and social service organizations. Beyond setting standards for how

Public Records, 116 YALE L.J. 1344, 1349 \& n.20 (2007) (describing tenant blacklists created by culling court records of eviction proceedings).

111. See Trial Court Rule XIV: Uniform Rules on Public Access to Court Records, MASs.GOV, http://www.mass.gov/courts/case-legal-res/rules-of-court/trial-court/tc-rule-14-records (last visited Apr. 6, 2017) [https://perma.cc/E6LY-5LSV] (granting attorneys access to electronic case records). The rule does not grant remote electronic access of audio, audiovisual, or electronic images to the public. See id. But see My Court Card Portal, SElfHelp.OCCOURTS, https://selfhelp.occourts.org (last visited Apr. 6, 2017) (creating self-help portal for public in Orange County, California).

112. See Peter W. Martin, Online Access to Court Records-From Documents to Data, Particulars to Patterns, 53 VILL. L. REV. 855, 864 (2008) (emphasizing technological progress ignoring general public and litigants). The federal courts did not establish computer-based case management systems or subsequent electronic filing and document management systems "to provide the public with better access to court records." Id. Those systems were created "because they offered major gains for judges and court administrators." Id.

113. See Joint Tech. Comm., Online Dispute Resolution and the Courts 1, 3 (Nov. 30, 2016), http://www.ncsc.org (to access follow perma.cc link) [https://perma.cc/CN58-JDVS] (explaining court use of ODR); REPORT ON THE FUTURE OF LEGAL SERVICES, supra note 85, at 19, 47 (recommending court-annexed ODR); Suzanne Van Arsdale, User Protections in Online Dispute Resolution, 21 HaRv. NegOt. L. ReV. 107, 109 (2015) (highlighting increased use of ODR). Additionally, expanding the use of ODR into the criminal justice context would clearly raise questions under the Confrontation Clause of the Sixth Amendment to the U.S. Constitution.

114. See OASIS Legal XML Online Dispute Resolution TC, OASIS, https://www.oasis-open.org (last visited Apr. 6, 2017) [https://perma.cc/2C69 -4C3L] (providing model data standards and technical committee for ODR). 
that data is shared, what would be required to implement those tools effectively? In addition to technology itself, the adoption of data standards offers a paradigm shift in the role of the courts as part of a larger justice ecosystem. This shift is long overdue. While courts are always included in broader multi-stakeholder discussions of access to justice, they are typically at arm's length, not subject to the oversight or critique of entities that represent court users, like the private bar or legal aid organizations.

Further, collaborations between justice system partners encounter two contradictory faces of state trial courts. Court leaders-particularly judgesplay an increasingly strong leadership role in promoting and setting priorities for collaborative access to justice initiatives. ${ }^{115}$ At the same time, most local and state-level court administrators generally do not partner with legal aid providers or other similar legal advocates on court-initiated efforts, even when it concerns implementing priorities that have been set out by judicial leadership.

We are beginning to see signs of a shift in this kind of thinking. The Public Welfare Foundation, building upon the Resolution for Meaningful Access to Justice for All, passed by the Conference of Chief Justices and Conference of State Court Administrators in 2015, created a competitive grant process to encourage state-level stakeholders to develop comprehensive, collaborative approaches to foster access to justice for all. ${ }^{116}$ Seven states received grants, and as of 2017, they are in the process of strategic action planning. ${ }^{117}$ The Justice for All grant process is but the latest example of an approach utilized by court systems, legal services providers, and access to justice commissions across the country. These approaches take stock of the legal needs and available resources within a jurisdiction and pilot solutions to observed legal needs. ${ }^{118}$

115. See, e.g., Jonathan Lippman, The Judiciary As the Leader of the Access-to-Justice Revolution, 89 N.Y.U. L. REV. 1569, 1569-70 (2014) (advocating for judicial leadership in access to justice movement); Richard Zorza, Access to Justice: The Emerging Consensus and Some Questions and Implications, 94 JUDICATURE 156, 156-57 (2011) (suggesting court has strong role in developing emerging consensus, including court simplification and triage); Gerry Singsen, Observing Change, 3, 6-7 MSBF.oRG, http://www.msbf.org /futuresandatj/Observing-Change-article.pdf (last visited Apr. 6, 2017) [https://perma.cc/42PC-GQFV] (recognizing judicial branch's role in access to justice realm).

116. See Justice for All, Justice For All Strategic Planning Guidance Materials 5-6 (Aug. 3, 2016), http://www.ncsc.org/ /media/Microsites/Files/access/Justice\%20for\%20All\%20Guidance\%20Materials \%20 Final.ashx [https://perma.cc/W4NG-NQPJ] (explaining importance of gathering all different stakeholders in court system); see also Justice For All Project, NAT'L CTR. FOR ST. CTS., http://ncsc.org/jfap (last visited Apr. 6, 2017) [https://perma.cc/2SSY-RAF4] (giving brief description of project).

117. See generally Justice For All Grants Announcement, NAT'L CTR. FOR ST. CTS. (Nov. 2016), http://www.ncsc.org/ /media/Microsites/Files/access/JFA\%20Awards\%20Announcement\%20Final.ashx [https://perma.cc/CT7A-U4XN] (announcing grant recipients).

118. See SANDEfur \& SMYth, supra note 90, at v (highlighting findings of legal service survey). But see Elizabeth L. MacDowell, Reimagining Access to Justice in the Poor People's Courts, 22 GEO. J. ON POVERTY L. \& POL'Y 473, 473 (2015) (noting access to justice initiatives prioritize access over justice). 
The Justice for All approach is somewhat novel in that it emphasizes collaboration and coordination across the justice system-including the state bar, legal aid providers, the state court system, social service providers, and others not traditionally considered access to justice stakeholders. Also, unique in the Justice for All process is the characterization of the courts as partners with the rest of the civil justice ecosystem.

For initiatives like Justice for All to be sustainable, they require more than an ad hoc approach to multi-stakeholder "strategic action planning." 119 They require a culture of communication and collaboration that does not yet exist. We believe that the process of developing and implementing data standards is the missing link that could lay the groundwork for communication and collaboration in other settings.

Strengthening the court's interoperability with other systems is one example of how data standards can initiate a conversation about the changing role of the courts in the larger justice ecosystem. Engagement with legal aid and the private bar can inform court decision-making and judicial education in ways that improve the system overall. Similar to the judicial decision-making process itself, judicial administration and court policy must become "deeply informed about the institutions with which legal actors interact," as well as informed by court users, particularly those without lawyers. ${ }^{120}$

Initiating a conversation about data sharing is often overlooked as a potential first step towards understanding court operations from the perspective of those who use the courts. Such an understanding is paramount in creating true "demand side reform."121 Through a collaborative effort with other stakeholders, state courts benefit from examining court processes from a user's perspective. Redesign efforts ${ }^{122}$ outline a process for mapping the court user experience, identifying gaps, recommending solutions to address issues, and experimenting with model solutions to assess their effectiveness. ${ }^{123}$

119. Justice For All Grants Announcement, supra note 117.

120. Michael C. Dorf, Legal Indeterminacy and Institutional Design, 78 N.Y.U. L. REV. 875, 882 (2003).

121. See Steinberg, supra note 54, at 786 (describing approaches for understanding court operations for low-income litigants).

122. See Redesigning Housing Court, NULAWLAB, http://nulawlab.org/view/redesigning-housing-court (last visited Apr. 6, 2017) [https://perma.cc/2Q4Q-UMD3] (giving example of court redesign experiment).

123. See generally Erika J. Rickard, The Agile Court: Evidence-Based Approaches to Improve Access to Justice and the Court User Experience, 39 W. NEw ENG. L. REv. (forthcoming May 2017) (discussing testing to evaluate effectiveness of innovation). Research and evidence-based approaches are in their infancy in the civil legal system. See, e.g., Laura K. Abel, Evidence-Based Access to Justice, 13 U. PA. J.L. \& Soc. Change 295, 297 (20109) (highlighting need for evidence-based approach in civil legal aid programs); D. James Greiner \& Andrea Matthews, Randomized Control Trials in the United States Legal Profession, 12 ANN. REv. L. \& SOC. SCI. 295, 295-312 (2016) (outlining the dearth of randomized control trials in the law); Deborah L. Rhode, Access to Justice: An Agenda for Legal Education and Research, 62 J. Legal Educ. 531, 533 (2013) (noting lack of research). 


\section{CONCLUSION}

Data standards are inevitable. They are a necessary ingredient for the success of current and future technological innovations. These standards will express the priorities of those organizations active in their creation or selection. The power to set standards, be it through creation or adoption, is the power to determine their impact and their value. As the forum for hearing disputes and the keeper of records in such, courts occupy a unique role. The courts themselves dictate the form by which individuals and institutions interact with the court system, and by extension, with one another. By leading a movement toward the acceptance of open data standards, courts stand to benefit by reducing the burden of creating new tools, and by providing a forum for stakeholder interaction. Those who stand to benefit most are low-to-moderateincome court users, the intended audience for many of the technology tools envisioned here.

Currently, court users are forced to run a gauntlet of overlapping and redundant services. Establishing governance and communication protocols in relation to standards will expand communication between institutions and legal actors, reducing the silo effect and generating more opportunities for courts to integrate feedback from users. The advent of data standards is not the only path forward. It is, however, a low-cost, high-reward investment, a mechanism for connecting technologies and driving conversations. Whether courts create new standards or adopt and expand existing ones, they should focus first on establishing a common language.

Data standards represent a foundation upon which we can build innovative technologies that will move beyond the status quo, allowing us to simplify court processes, and transform court systems to better serve the needs of their users. 